\title{
A Global Classroom for International Sustainability Education
}

\author{
Arnim Wiek ${ }^{1}$, Michael J. Bernstein ${ }^{1}$, Manfred Laubichler ${ }^{2,3,4}$, Guido Caniglia ${ }^{2}$, \\ Ben Minteer ${ }^{2}$, Daniel J. Lang ${ }^{5}$ \\ ${ }^{1}$ School of Sustainability, Arizona State University, Tempe, USA \\ ${ }^{2}$ School of Life Sciences, Arizona State University, Tempe, USA \\ ${ }^{3}$ Santa Fe Institute, Santa Fe, USA \\ ${ }^{4}$ Marine Biological Laboratory, Woods Hole, USA \\ ${ }^{5}$ Institute of Ethics and Transdisciplinary Sustainability Research, Faculty Sustainability, \\ Leuphana University of Lüneburg, Lüneburg, Germany \\ Email: arnim.wiek@asu.edu
}

Received February $11^{\text {th }}$, 2013; revised March $15^{\text {th }}$, 2013; accepted March $27^{\text {th }}, 2013$

\begin{abstract}
Copyright (c) 2013 Arnim Wiek et al. This is an open access article distributed under the Creative Commons Attribution License, which permits unrestricted use, distribution, and reproduction in any medium, provided the original work is properly cited.
\end{abstract}

\begin{abstract}
Sustainability studies put emphasis on social-environmental-technical problems with local manifestations and global impacts. This makes especially poignant the need for educational experiences in which students confront the challenges of crossing cultural, national, and geographical boundaries in a globalized world and understand the historical, epistemological and ethical underpinnings of these diverse cultural conditions. The success criteria to evaluate the educational experiences demanded by the globalization of education, however, are yet to be specified and used in novel educational opportunities. A brief review of international sustainability education options currently available to students reveals a gap between the knowledge students may need to succeed in a globalized world and the opportunities available. Into this landscape, we introduce The Global Classroom, an international collaboration between Leuphana University of Lüneburg in Germany and Arizona State University in the US. The project strives for an interdisciplinary and cross-cultural approach to equipping students with the knowledge, skills, and attitudes required to take on sustainability challenges in international settings. We discuss the structure and organization of the Global Classroom model and share preliminary experiences. The article concludes with a reflection on institutional structures conducive to providing students with the international learning opportunities they may need to tackle sustainability problems in a globalized world.
\end{abstract}

Keywords: Sustainability Education; International Education; Project- and Problem-Based Learning; Interdisciplinary Education

\section{Introduction}

Sustainability challenges, including climate change, loss of biodiversity, poverty, epidemics, and violent conflicts, manifest at specific locations; yet, the underlying causes are linked to other regions, nations, and even the global society. Hence, potential mitigation and solution options require coordinated and collaborative efforts around the world (Van der Leeuw et al., 2012). The coming generations of decision-makers, government agents, entrepreneurs, farmers, engineers, consultants, and others will have to face these challenges while collaborating across local, regional, national, geographical, and cultural boundaries. Collaboration of this extent requires the broad acquisition of specific competence, knowledge, skills, and attitudes, which in return has major implications for teaching and education (de Haan, 2006; Rowe, 2007; Sipos, 2008; Brundiers \& Wiek, 2011).

With these new teaching challenges, educators must determine how to best equip students with these trans-boundary competencies. Classroom exercises that present sustainability problems and solution options are an important part of such a competency-focused approach. These classroom exercises, however, lack the cross-cultural and real-world experience that is critical for developing competencies that account for the local nuances of sustainability problems and solutions. There is a particular need for diverse and rich cross-cultural learning opportunities that simultaneously prepare students for understanding sustainability challenges and build student capacity to develop robust solution options to these challenges.

The success criteria or general learning objectives for such international educational experiences can be summarized as follows. Students need to be capable of working across national, geographical, and cultural boundaries, recognizing the cultural, historical, epistemological and ethical context of perceiving sustainability problems and developing solution options; and drawing on a pool of internationally-sourced solution ideas that can, when adapted, be transferred to different local contexts. Students ought to become:

- Sensitive to cultural differences and their historical origins (general cultural sensitivity).

- Attuned to how sustainability problems and potential solutions differ in diverse local contexts (context-specific problem and solution orientation).

- Recognize, distill, adapt, and transfer sustainability knowledge, problem-solving frameworks, concepts, and best prac- 
tices to local settings (problem-solving through adaptation and transfer).

- Integrate perceptions, knowledge, and skills across different disciplines and communities of practice in order to comprehensively understand sustainability challenges and their ethical implications and to develop evidence-based solution options (interdisciplinarity).

- Capable of working in teams composed of individuals with diverse cultural backgrounds (cross-cultural teamwork).

In the following, we briefly review international sustainability education options that are currently available to students and summarize the strengths and weaknesses of these education options. Against this review background, we present the concept and structure of the Global Classroom, an international collaboration between Leuphana University of Lüneburg in Germany and Arizona State University in the US. The Global Classroom offers cross-cultural and interdisciplinary educational experiences with the intent to equip students with the knowledge, skills, and attitudes required to take on sustainability challenges in international settings. We conclude the article with a discussion of institutional structures best suited to provide students with such international learning opportunities.

The article offers a tangible example of how to provide international educational opportunities in line with the general criteria for advanced sustainability education. We hope the article provides a valuable source of inspiration for other universities to initiate similar efforts or expand ongoing ones.

\section{International Opportunities for Sustainability Education}

Universities are in the process of recognizing the need for shifting and transforming established structures and practices in research, teaching, and operations in order to meet the sustainability challenges of the 21st century (Ferrer-Balas et al., 2008; Whitmer et al., 2010; Wiek et al., 2011b; Lang \& Wiek, 2012). One important domain of this transformation is the emergence of international educational programs in sustainability. We first review the current state of international sustainability education opportunities through the lens of 17 international programs featured by the Association for the Advancement of Sustainability in Higher Education (AASHE). AASHE is a support network for educational organizations to advance sustainability in teaching, research, and operations. AASHE maintains a list of sustainability study abroad programs offered by various organizations across the US ${ }^{1}$. We limit our review to academic institutions (as opposed to including other organizations) providing undergraduates with sustainability study abroad opportunities. While not comprehensive, the selected 17 programs present a robust spectrum of opportunities currently available to students in the US. We reviewed these programs based on the information available on the web (we did not request further information, conduct interviews, etc.). For the purpose of this review, we sought only information easily and readily accessible to students landing on the program page.

We use a review scheme based on the quality criteria for international sustainability education in a globalized world we explored above. For each program we asked the following questions.

In how far does this program:

- Promote cross-cultural education?

${ }^{1}$ Available at: http://www.aashe.org/about/aashe-mission-vision-goals
- Address the context-specificity of sustainability problems and potential solutions?

- Offer capacity-building in complex problem-solving (solution orientation)?

- Adopt an interdisciplinary approach to sustainability problems and potential solutions?

- Teach teamwork in cross-cultural settings?

To keep our review cursory, as intended, we reviewed if an element was either "strong," predominantly "absent," or "not clear" from available material. We formulated our answers based on keywords and phrases available on program landing pages. In particular, we focused on sentences beginning with phrases like, "The program is designed [...]" or "this program's goal [...]" or "students will explore [...]" For example, the phrase to provide "students with an opportunity to learn about contemporary and historical issues that impact development and social change in Southern Africa" is deemed a "strong" opportunity for cross-cultural education. The phrase, "This course will examine watershed management and its role in sustainable development," represents a "strong” solution orientation; use of the word "transdisciplinary" indicated a "strong" interdisciplinary approach. The statement that students will, "cross borders, working collaboratively to solve problems" is deemed evidence of "strong" teamwork in cross-cultural settings (Table 1).

The majority of international sustainability education opportunities we reviewed lasted between one and two months (Table 2).

Our review reveals that a majority of programs (14 of 17) provide students with a cross-cultural educational opportunity (Table 1). The majority of programs available address the context-specificity of sustainability problems and potential solutions (10 of 17); slightly fewer build capacity in complex problem-solving (solution orientation) (8 of 17), or adopt an interdisciplinary approach (8 of 17; 3 additional programs may, but this was "not clear" from available information). Our review reveals a dearth of programs offering students experience to work on cross-cultural teams (1 of 17). Only one program meets all of the presented criteria for international sustainability education opportunities (Table 3).

\section{The Global Classroom Experiment}

Into this landscape, we introduce The Global Classroom, an international collaboration between Leuphana University of Lüneburg in Germany and Arizona State University in the US.

\section{Background}

During the academic year 2009/2010, an international group of fellows in residence at the Institute for Advanced Studies in Berlin (Wissenschaftskolleg zu Berlin) formed a working group on curriculum reform. These fellows represented a wide range of disciplines (from physics and biology to political science and art history) and geographical regions (US, Europe, India, Israel). The group produced a manifesto and a set of recommendations (see: http://curriculumreform.org; Elkana et al., 2010). The central recommendation was to prepare students from the beginning of their studies to understand and deal with real-life problems at a global scale and to understand contextual (geographical, cultural) dimensions of knowledge.

Based on these discussions, the group began to explore the 


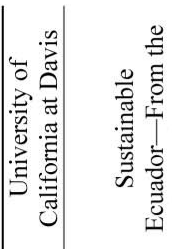

可

ซิ .]

$=4$

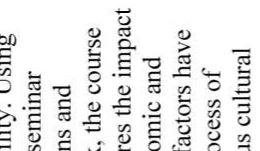

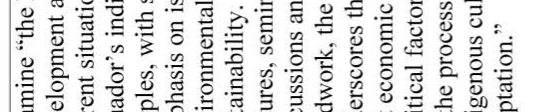

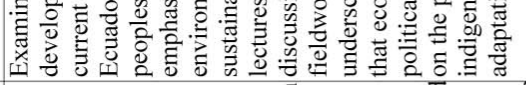

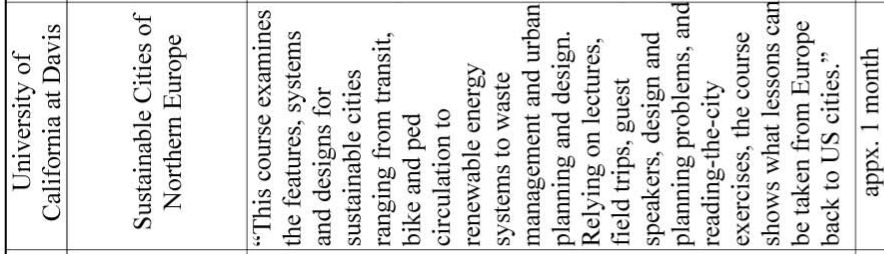

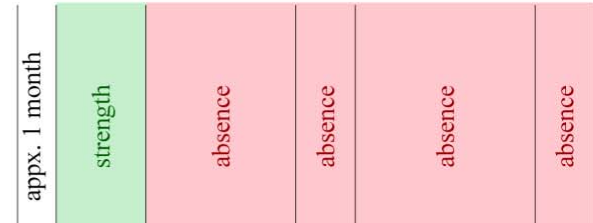

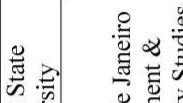

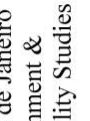

a $\frac{\overline{0}}{9}=$

象:

产

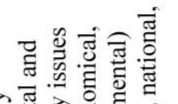

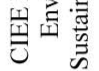

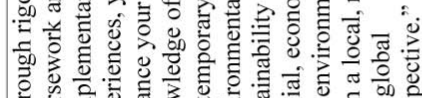

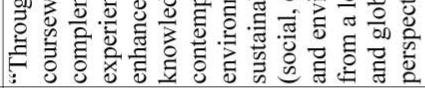

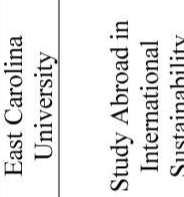

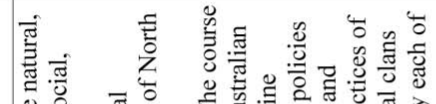

要要

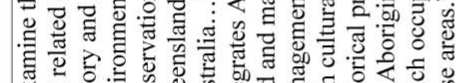

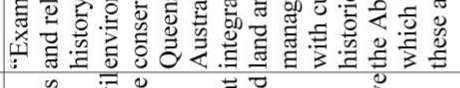

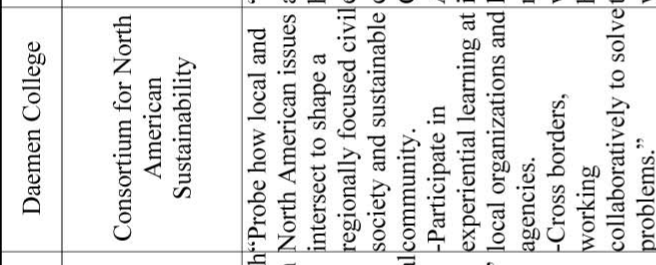

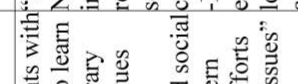

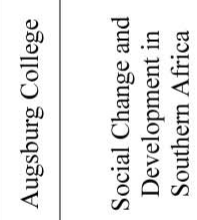

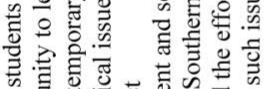

कs

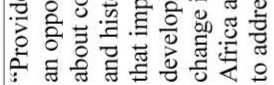

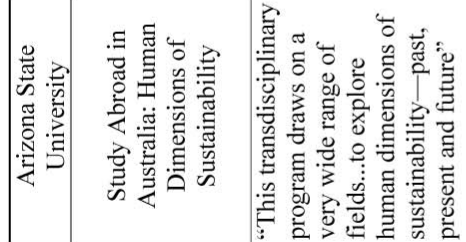

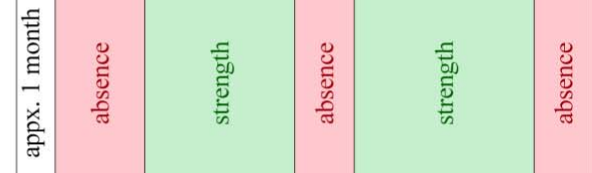

穿

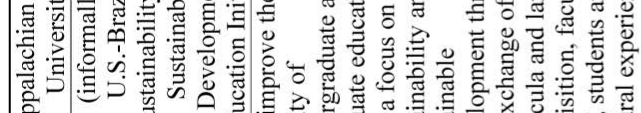

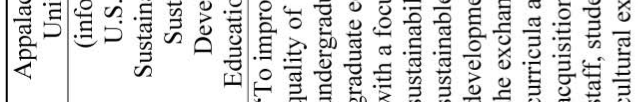

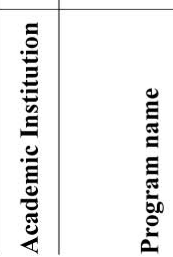

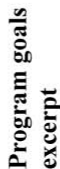

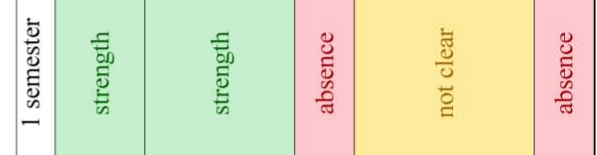

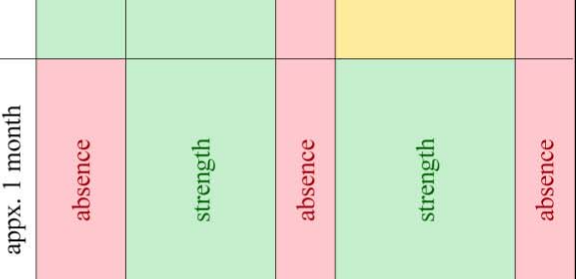

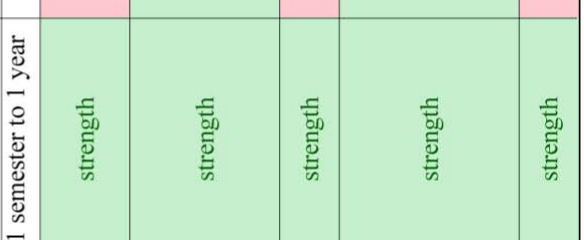

热言
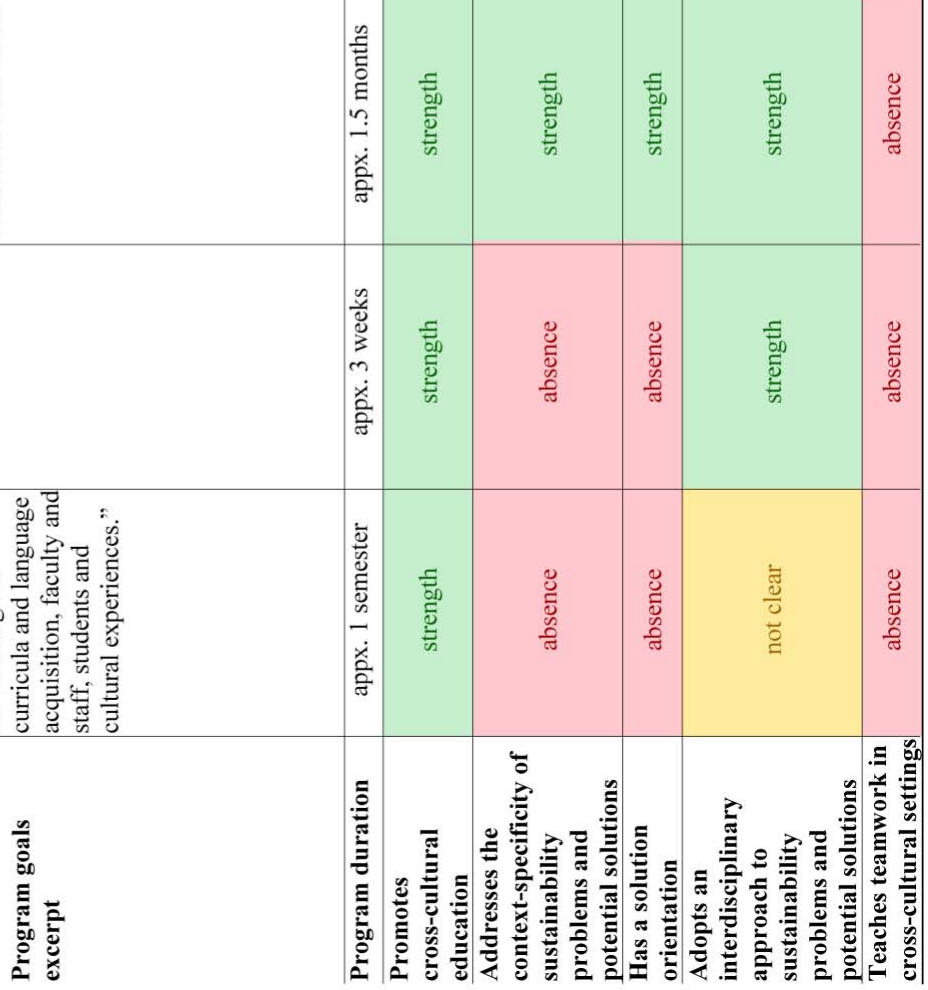


\begin{tabular}{|c|c|c|c|c|c|c|c|c|}
\hline $\begin{array}{ll}0 \\
0 \\
0\end{array}$ & 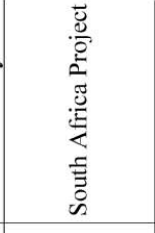 & 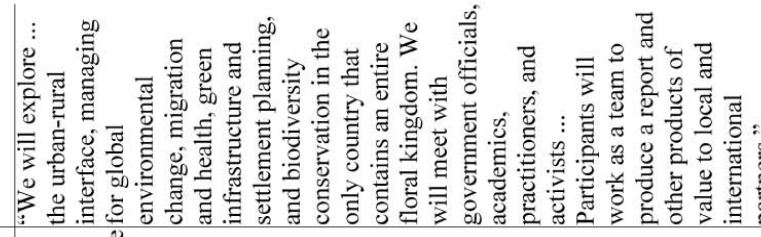 & 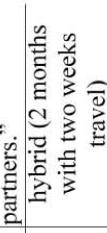 & 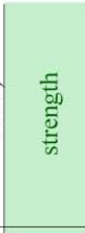 & 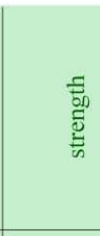 & 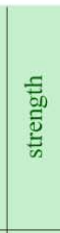 & $\begin{array}{l}\frac{5}{50} \\
\bar{E} \\
\frac{5}{5} \\
\frac{5}{5}\end{array}$ & 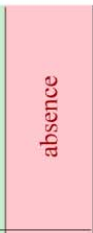 \\
\hline $\begin{array}{ll}0 \\
0 \\
0\end{array}$ & 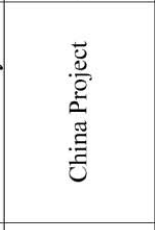 & 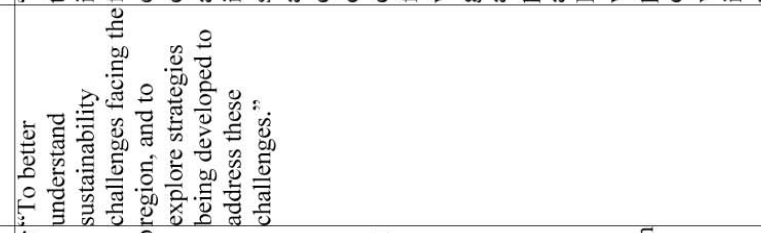 & \begin{tabular}{l}
$\frac{\tilde{u}}{\ddot{\Xi}}$ \\
3 \\
\multirow{2}{*}{}
\end{tabular} & 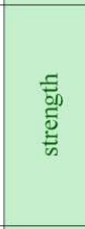 & 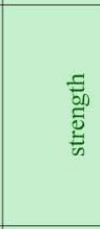 & 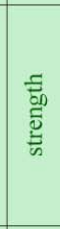 & $\begin{array}{l}\frac{5}{50} \\
\frac{5}{5} \\
\frac{5}{5}\end{array}$ & 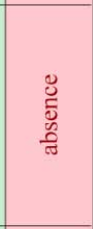 \\
\hline 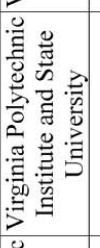 & 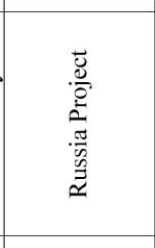 & 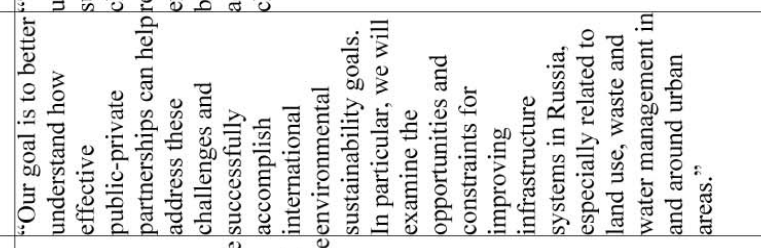 & 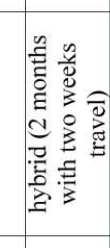 & 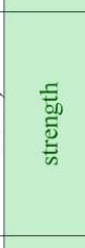 & 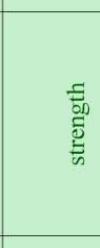 & 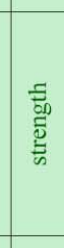 & 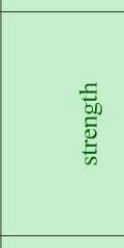 & 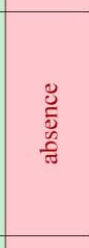 \\
\hline $\begin{array}{ll}0 \\
0 \\
0\end{array}$ & 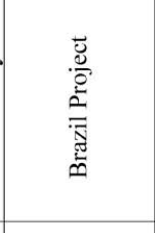 & 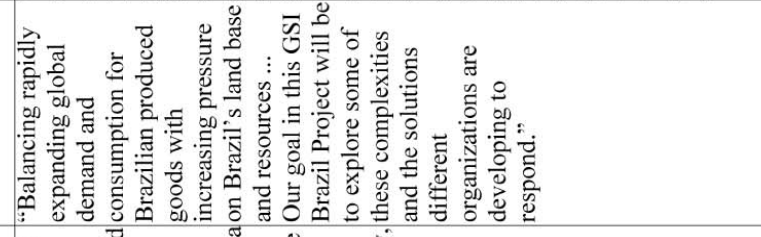 & 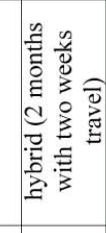 & 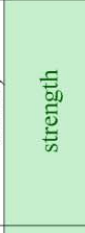 & 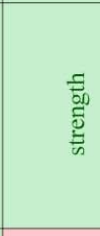 & 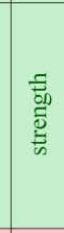 & 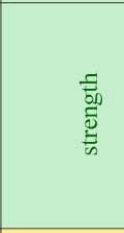 & 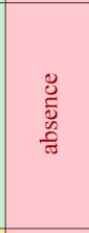 \\
\hline 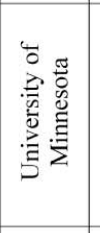 & 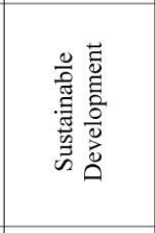 & 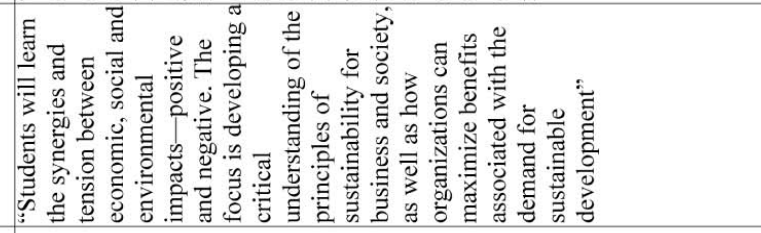 & 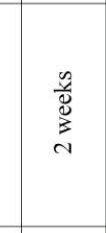 & 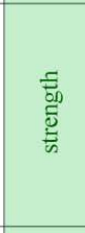 & 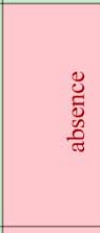 & 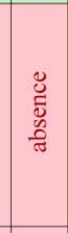 & 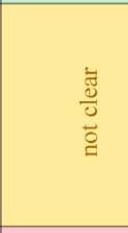 & $\begin{array}{l}\text { : } \\
\text { 总 } \\
\text { 恶 }\end{array}$ \\
\hline 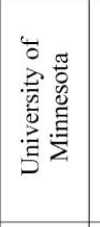 & 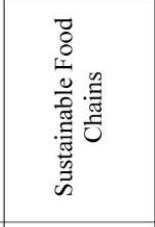 & 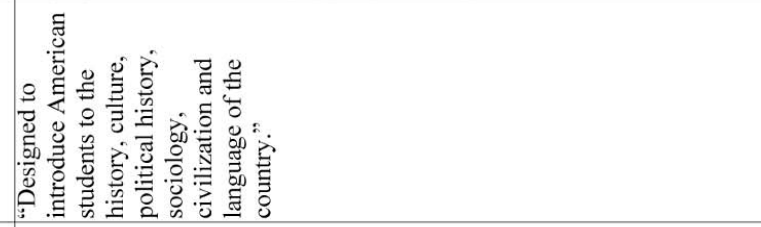 & 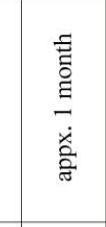 & 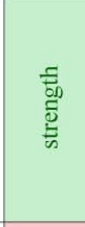 & 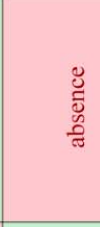 & 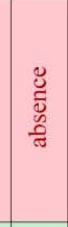 & $\begin{array}{l}\ddot{\Xi} \\
\bar{\Xi} \\
\text { है }\end{array}$ & $\begin{array}{l}\text { : } \\
\text { 总 } \\
\text { 尊 }\end{array}$ \\
\hline 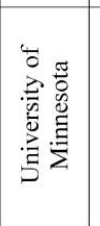 & 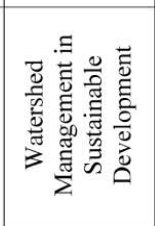 & 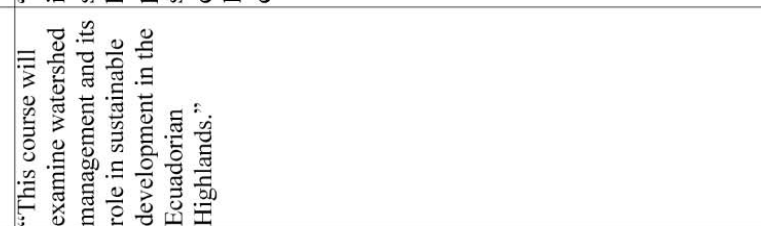 & 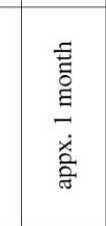 & 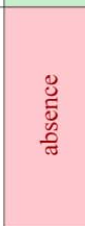 & 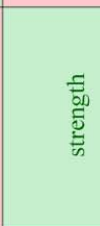 & 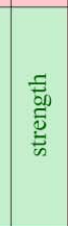 & 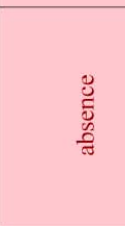 & 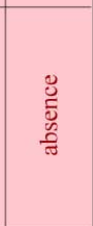 \\
\hline 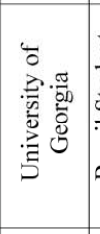 & 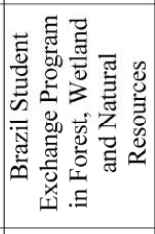 & 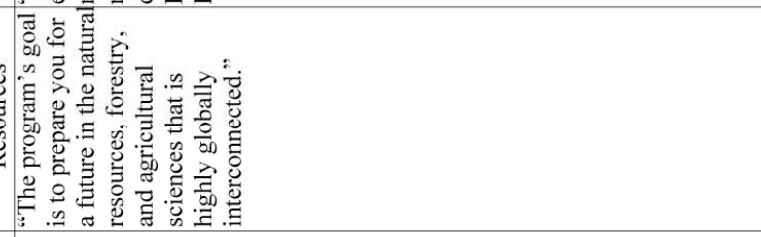 & 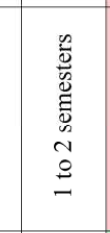 & 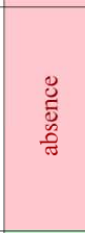 & $\begin{array}{l}\text { : } \\
\text { हूँ } \\
\text { हैं }\end{array}$ & $\begin{array}{l}\mathscr{0} \\
\text { एँ. } \\
\text { तै }\end{array}$ & 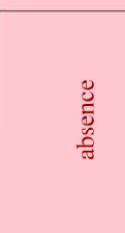 & $\begin{array}{l}\text { : } \\
\text { : } \\
\text { हू. }\end{array}$ \\
\hline 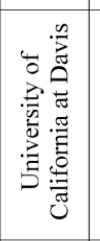 & 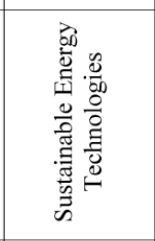 & 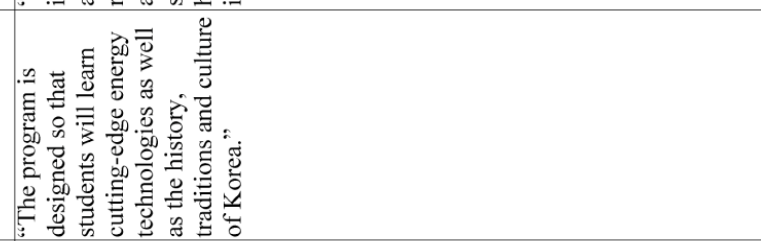 & 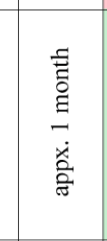 & 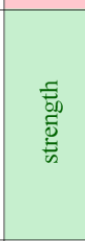 & 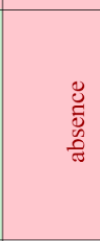 & 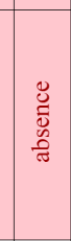 & 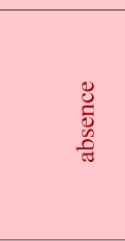 & 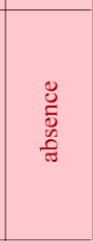 \\
\hline 氖氖 & 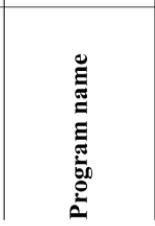 & 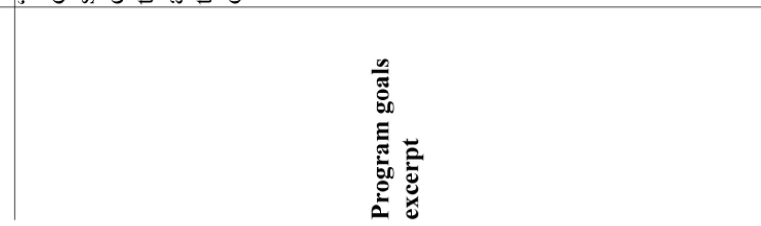 & 竧 & 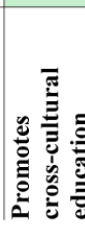 & 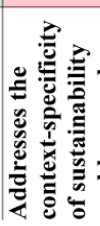 & 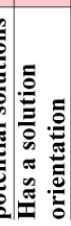 & 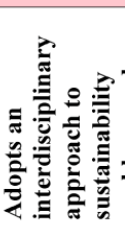 & 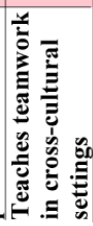 \\
\hline
\end{tabular}


Table 2.

Duration of the reviewed international programs.

\begin{tabular}{cccc}
\hline Program duration & $1-2$ semesters & $1-2$ months & $1-3$ weeks \\
\hline Number of programs & 4 & 7 & 3 \\
\hline
\end{tabular}

Table 3.

Narrowing of the opportunity space for students in international sustainability education as more quality criteria are applied.

\begin{tabular}{|c|c|c|c|c|c|}
\hline $\begin{array}{l}\text { Number of programs } \\
\text { evaluated }\end{array}$ & $\begin{array}{l}\text { Number of programs } \\
\text { promoting cross-cultural } \\
\text { education }\end{array}$ & $\begin{array}{l}\text { Number of programs } \\
\text { promoting cross-cultural } \\
\text { education AND } \\
\text { addressing context } \\
\text { specificity }\end{array}$ & $\begin{array}{l}\text { Number of programs } \\
\text { promoting cross-cultural } \\
\text { education AND } \\
\text { addressing context } \\
\text { specificity AND having a } \\
\text { solution orientation }\end{array}$ & $\begin{array}{l}\text { Number of programs } \\
\text { promoting cross-cultural } \\
\text { education AND } \\
\text { addressing context } \\
\text { specificity AND having a } \\
\text { solution orientation AND } \\
\text { adopting an } \\
\text { interdisciplinary approach }\end{array}$ & $\begin{array}{l}\text { Number of programs } \\
\text { promoting cross-cultural } \\
\text { education AND } \\
\text { addressing context } \\
\text { specificity AND having a } \\
\text { solution orientation AND } \\
\text { adopting an } \\
\text { interdisciplinary approach } \\
\text { AND teaching } \\
\text { cross-cultural teamwork }\end{array}$ \\
\hline $\begin{array}{llll}\bullet & \bullet & \bullet & \bullet \\
\bullet & \bullet & \bullet & \bullet \\
\bullet & \bullet & \bullet & \bullet \\
\bullet & \bullet & \bullet & \bullet \\
\bullet & & & \end{array}$ & $\begin{array}{llll}0 & 0 & 0 & 0 \\
0 & 0 & 0 & 0 \\
0 & 0 & 0 & 0 \\
0 & 0 & & \end{array}$ & $\begin{array}{llll}\bullet & \bullet & 0 & 0 \\
\bullet & \bullet & \bullet & \bullet \\
\bullet & \bullet & \bullet & \end{array}$ & $\begin{array}{llll}\bullet & \bullet & \bullet & \bullet \\
\bullet & \bullet & \bullet & \end{array}$ & $\begin{array}{llll}\bullet & \bullet & \bullet & \bullet \\
\bullet & \bullet & & \end{array}$ & • \\
\hline 17 & 14 & 11 & 7 & 6 & 1 \\
\hline
\end{tabular}

possibility of an educational pilot that would allow pursuing these recommendations. Of the institutions represented in this group, Arizona State University (ASU) and Leuphana University of Lüneburg (LUL) provided the best opportunity to conduct a pilot project. Both universities had recently begun a process of radical transformation that challenged traditional conceptions of research and education (Crow, 2010; Lang \& Wiek, 2012), similar to other universities around the world (Ferrer-Balas et al., 2008); professional relationships (student exchange, co-teaching, joint supervision, etc.) already existed among faculty and students from both institutions; and both institutions were willing to facilitate and support a pilot in global education for continuation and expansion, beyond a oneoff experiment.

A new group emerged from these initial discussions that was tasked to develop the Global Classroom as an integrated joint program between ASU and LUL for 12 credit hours (US) or 30 credit points (Germany) that would run over 3 semesters and initially involve three overlapping cohorts of 40 students each (20 from each institution). With this idea, the group successfully approached the Stiftung Mercator for funding. Through a series of virtual and in-person meetings involving faculty members, post-docs and teaching assistants from both institutions, we developed an integrated curriculum and a technology platform for start in January 2013.

\section{Basic Features}

The initial Global Classroom focuses on one topic-Sustainable Cities-and approaches it from a variety of perspectives, including sustainability studies, sociology, social geography, history, history and philosophy of science and medicine, environmental ethics, and economics. The background of the first cohort of students is equally diverse. Applying the princeples of the curriculum reform manifesto as well as similar efforts in re-conceptualizing sustainability education (Wiek et al., 2011b), the Global Classroom is built on a hands-on, collabora- tive research model that is inquiry-based, problem-driven, context-sensitive and solution-oriented. By combining interdisciplinary liberal arts approaches based on historical, epistemological, ethical and sociological analyses with a problem- and solution-oriented sustainability science research educational model, the Global Classroom uses virtual technologies to educate students on ways to engage and contextualize complex sustainability problems. The Global Classroom adopts methodology and computational tools developed in other educational projects to facilitate teaching and learning. These include the Embryo Project (http://embryo.asu.edu), which developed workflows and manuals for peer review, writing and publishing based on modular research projects; system thinking approaches to sustainability challenges; mapping methodologies inspired by urban sociology; walking methods developed in the fields of urban studies, photography, and sociology; and a Problem- and Project-Based Learning (PPBL) approach developed in the School of Sustainability at ASU (Wiek et al., 2013). The Global Classroom is built on the understanding that when we deal with problems in isolation, without recognition of broader context and cause, we fail to generate effective, lasting solutions. Our educational institutions have a long record of successfully training topical experts with narrowly constrained skill sets. The Global Classroom draws off of these critical basic knowledge foundations. But where current educational institutions seek only to better understand urban systems, the Global Classroom builds capacity for generating knowledge that sustainability change-makers - be they researchers, practitioners, or general citizens - can use to advance urban sustainability in addition to gaining a broader contextual understanding of these issues.

To equip students with the knowledge and tools they need to systematically engage urban sustainability challenges and drive toward positive change, the Global Classroom pairs an inquiry-based mode of researching and experiencing the city with a sustainability competency approach to education. Furthermore, the Global Classroom provides students with the skills to 
analyze the historical, epistemological and ethical foundations of these problems. A competency framework provides a "converging set of key competencies that can guide the design of programs and courses in sustainability, teaching and learning evaluations" (Wiek et al., 2011a). The key competency framework proposes five domains of knowledge and skill as critical to sustainability science research and education: systems thinking, anticipatory thinking, normative thinking, strategic thinking, and interpersonal skills (ibid.). Table 4 illustrates how learning outcomes of the Global Classroom map onto key competencies.

The Global Classroom is designed and taught by an international team of faculty and graduate students, drawing on diverse disciplinary backgrounds from sustainability to biology to philosophy to environmental ethics, promoting an interdisciplinary approach. The Global Classroom engages in the first cohort 22 ASU undergraduate students and 20 LUL undergraduate students of diverse disciplinary backgrounds from art, psychology, biology, sustainability, and others.

The students both in Germany and in the United States start with an open exploration of their cities. From the beginning, they work in international teams on collaborative projects that get refined over the course of the three semesters. The research projects include a focus on context-specific sustainability challenges, using problem- and project-based learning approaches (Steinemann \& Asce, 2003; Thomas, 2009; Yasin \& Rahman, 2011; Wiek et al., 2013) but also emphasize the various contextual factors needed to fully comprehend the issues. For example, in Phoenix, students have the opportunity to focus on water resource management, urban sprawl, or urban heat island; in Lüneburg, students have the opportunity to focus on sustainability-oriented business development, energy transitions, and urban-rural development tensions. In both cases, students will also investigate the larger cultural context and historical constraints for all these issues. Student research teams are expected to investigate not just urban sustainability challenges, but also potential solutions, focusing on lessons to be learned from sustainability advancements in Phoenix, and Lüneburg, and around the world.

Active exploration of the cities is complemented by discussion and instruction in background knowledge on cities, sustainability, history, ethics, etc. To this end, online-material is provided for discussion in the joint transatlantic sessions enabled by the use of Vydio ${ }^{\circledR}$ technology. Other electronic teaching and communication platforms, such as social media and discussion forums, accompany in-class presentations and discussions. Funding from Stiftung Mercator allows for two exchange visits to the partner university by each cohort. During the first visit, students refine, defend, and plan their group research projects; during the second one they finish up and present their findings in an open event.

\section{Modular Design}

The Global Classroom curriculum on urban sustainability unfolds over three semesters spanning three core stages combining problem-based and solution-oriented sustainability approaches with perspectives from history and philosophy of science as well as ethics (Figure 1). Each student's resident cities, Phoenix and Lüneburg, frame case studies for urban challenges.

Each of the six modules engage students through a suite of diverse content, context, and methodologies framed, augmented, and achieved through teamwork, stakeholder engagement, and

Table 4.

Linking learning outcomes of the global classroom to sustainability key competencies.

\begin{tabular}{|c|c|c|c|}
\hline Systems thinking & Anticipatory thinking & Normative thinking & Strategic thinking \\
\hline $\begin{array}{l}\text { Analyze complex feedbacks among } \\
\text { cross-sector and cross-scale urban } \\
\text { sustainability challenges, like land-use } \\
\text { change and energy consumption, as } \\
\text { well as path dependencies that } \\
\text { constrain directions of development in } \\
\text { society, as with transportation }\end{array}$ & $\begin{array}{l}\text { Create and craft plausible sustainability } \\
\text { visions (desirable future states), for } \\
\text { example a vision of healthy and livable } \\
\text { urban communities. }\end{array}$ & $\begin{array}{l}\text { Evaluate implications of and trade-offs } \\
\text { among different conceptions of the city, } \\
\text { different motivations for development, and } \\
\text { alternative visions of the future; assess } \\
\text { how different worldviews shape the reality } \\
\text { of a city. }\end{array}$ & $\begin{array}{l}\text { Develop strategies to support } \\
\text { change in different societal } \\
\text { contexts, for example a strategy } \\
\text { for initiating and maintaining } \\
\text { urban agriculture. }\end{array}$ \\
\hline
\end{tabular}
infrastructure.

Interpersonal skills

Engage, motivate, collaborate with peers, decision-makers, stakeholders, and the public.

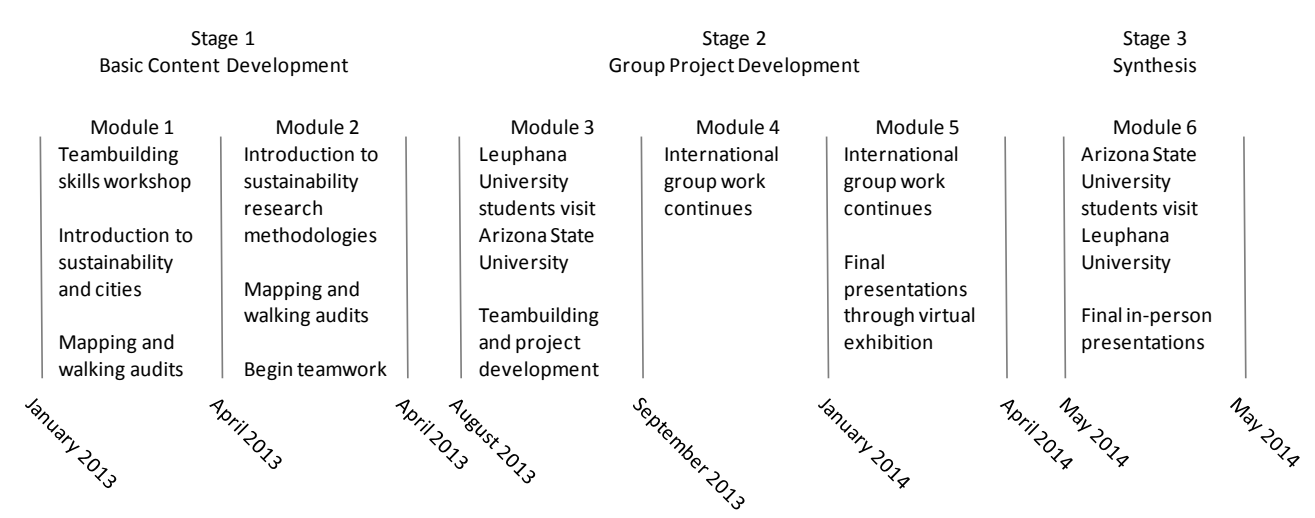

Figure 1.

Working model for the stages and modules of the Global Classroom. 
international collaboration.

\section{Content}

The content component of each module becomes the entry point for student engagement with sustainability problems. By building systemic understanding of urban sustainability challenges and pushing students to grapple with the potential outcomes of different societal trajectories and evaluate the implications of these trajectories, the content component empowers students with a nuanced, holistic appreciation for the complexity of the urban environment.

Students review the broad history of urban development; learn about current urbanization challenges related to population growth, social and demographic change, land-use landcover change, water and energy systems, decision making, and infrastructure decay; encounter visions of sustainable cities and successful responses to urban challenges; and develop an understanding of how change happens in cities. When synthesized and framed in a problem-based and solution oriented context, the knowledge developed in the content section provides a foundation for place-based, student-driven research on solution development. In addition, students will also further explore the historical origins and ethical challenges behind all these sustainability solutions.

\section{Context: The "Local” Case Study}

Just as an individual brings his/her own experience to bear on an issue and uses his/her experience as a medium of exchange in dialogue with his/her peers, the context component, here urban sustainability issues in Phoenix and in Lüneburg, will be the medium of engagement and exchange for Global Classroom students. By challenging students to apply their competencybased approach to conceive of specific urban sustainability problems in Phoenix and in Lüneburg, the context component equips students with place-based issues on which to engage their international peers. By collaborating across cities as different as Phoenix and Lüneburg students cultivate an appreciation for the diversity of urban sustainability challenges and solutions. Through engaging specific place-based challenges and learning about different problems shared or unique to different cities and cultures around the world, students bring richer perspectives to problem conceptualization and solution-oriented research.

\section{Research Methodology}

Throughout each module, instructors cultivate an appreciation of exploring knowledge gaps. They discuss different types of knowledge generated by different types of research and how to apply different methods of knowledge generation when undertaking solution-oriented sustainability research. Furthermore, they will also convey to students how to critically evaluate, reflect and problematize these solutions and their constraints in light of historical, epistemological, and ethical considerations. Students obtain a broad methodological skill set to perform solution-oriented sustainability research. In addition to learning the importance of a dialectic approach to critical engagement, students are being introduced to problem analysis, sustainability visioning, and transition strategy development methods.

\section{Teamwork}

The complexity and diversity of sustainability challenges calls for a collaborative approach to problem and solution research. Students in the Global Classroom tackle sustainability research challenges in international and interdisciplinary teams to prepare them for this reality. By supplementing knowledge cultivation with professional skills development, including project management, team document organization, meeting facilitation, conflict resolution, and virtual collaboration, the Global Classroom provides students with an experience base on which to draw for future professional work and research.

\section{International Collaboration and Virtual Teamwork}

The majority of sustainability challenges have global causes and implications. The Global Classroom experience is designed to address problems of this scope by having students study local problems and then engage with international peers to develop a richer understanding of how global problems manifest differently (and similarly) in other local contexts. The Global Classroom allows students to explore not just different cities, but also cultures. Students develop an appreciation for diverse values and perceptions influence sustainability challenges and solutions. By providing coaching support and virtual platforms for international communication, the Global Classroom builds student capacity for cross-cultural collaboration, a critical ingredient for interacting successfully in a globally interconnected world. The Global Classroom project pursues the goals of international education as a hybrid course that takes advantage of new media, technology, and learning theory. In addition, students gain first-hand experience with cutting-edge tools in video communication, online course environments, and online project presentation. Collaborative virtual group workspaces for participants and an online course environment that houses supporting course resources complete the Global Classroom learning environment.

\section{Initial Experience with the Global Classroom}

In light of our review of international sustainability education opportunities, we find the Global Classroom enriches the options available in the landscape of international sustainability education. Below, we discuss the ability of this model to deliver on quality criteria for international sustainability education; we present our plan for formative and summative assessments of student performance and program learning objectives; and we delve into the challenges (expected and experienced) of implementing the program, as well as strategies for coping with experienced challenges.

\section{Continuous Assessment}

To succeed in addressing sustainability challenges in a globalized world, students need to be capable of working across cultures, recognize cultural contexts, and draw upon a pool of internationally-applied ideas that can, when adapted, be transferred to different local contexts. The Global Classroom project provides various opportunities to acquire these capabilities through international education.

Global Classroom students work in international team on diverse place-based sustainability challenges in Phoenix and Lüneburg. As they shape their research, students are constantly challenged to combine the perspectives of international team members. In this way, students gain first-hand experience with cross-cultural teamwork and the different norms, perspectives, 
and approaches of their peers. Additionally, students and instructors draw on diverse epistemological backgrounds to craft research questions - teams composed of students from the arts, psychology, biology, sustainability and other programs are being coached by instructors to tackle urban sustainability issues that do not recognize disciplinary boundaries. Student teams not only delve into sustainability problems, but are also encouraged to research potential solutions-drawing from German, US, and international expertise across disciplines. This includes recognizing, distilling, transferring, and adapting sustainability knowledge, problem-solving frameworks, concepts, and best practices to local settings.

For continuous improvement, we are instituting a range of formative assessments to help us evaluate student learning and course effectiveness. One of our approaches to evaluating effectiveness is through the sustainability key competencies framework (Wiek et al., 2011a). Adopting the competencies framework allows for a comprehensive set of proxies for many of the quality criteria of international sustainability education outlined above (Table 5). For example, practice in cross-cultural teamwork develops interpersonal skills; synthesizing interdisciplinary perspectives to tackle an urban sustainability problem builds capacity in systems think about complex webs of influence among, say, infrastructure and political power.

We are evaluating the development of student competencies though pre-, interim-, and post-assessments that will be coded, with standards of inter-rater reliability, at the conclusion of the first cohort. In addition, we conduct periodic student-student, student-instructor, and instructor-instructor reviews to allow for ongoing formative assessment of the structural aspects of the Global Classroom itself (e.g., effectiveness of virtual platforms, relevance of content, availability of instructor support, sources of conflict, course strengths and areas of improvement, etc.).

\section{Challenges}

At times, the vision of the Global Classroom runs up against the reality of university logistics, virtual collaboration, and other challenges. Below, we explore a few of these challenges we have encountered and coping strategies we have adopted as the program develops.

\section{Time Zones and University Logistics}

In conducting a three semester long collaboration, as opposed to shorter international courses as exhibited in many of the international sustainability education options, two logistical challenges arise. The first challenge occurs at the micro-level: the day-to-day issues of communicating with partners across an 8-hour time difference. Time zones present a two-fold challenge related to when classes can be held (either far earlier than normal for one institution or far later for another), and when faculty can find time to collaborate and plan for classroom and program activities. E-mail, video conferencing services, and the cloud-based software packages each present important tools for the Global Classroom to span the international dateline and communicate synchronously and asynchronously. As we discuss later, however, such technological solutions come with their own issues.

The second challenge occurs at the macro-level: the weekto-week, month-to-month, and semester-to semester issues of teaching a course simultaneously at two universities with significantly different semester calendars. Semester start- and end-dates, and holiday schedules perforate Global Classroom calendars. But these challenges also offer opportunities as they enable us to take advantage of non-overlapping semesters to organize exchange visits to Phoenix and Lüneburg, respectively.

Table 5.

Exemplary use of sustainability key competencies as indicators for meeting criteria of international sustainability education opportunities.

\begin{tabular}{|c|c|c|c|c|c|}
\hline & $\begin{array}{l}\text { Promote cross-cultural } \\
\text { education }\end{array}$ & $\begin{array}{l}\text { Address the } \\
\text { context-specificity of } \\
\text { sustainability problems and } \\
\text { potential solutions }\end{array}$ & $\begin{array}{l}\text { Have a solution } \\
\text { orientation }\end{array}$ & $\begin{array}{l}\text { Adopt an interdisciplinary } \\
\text { approach to sustainability } \\
\text { problems and potential } \\
\text { solutions }\end{array}$ & $\begin{array}{l}\text { Teach teamwork in } \\
\text { cross-cultural settings }\end{array}$ \\
\hline $\begin{array}{l}\text { Systems } \\
\text { thinking }\end{array}$ & $\begin{array}{l}\text { Differences in urban } \\
\text { decision-making contexts } \\
\text { leading to different } \\
\text { physical landscapes. }\end{array}$ & $\begin{array}{l}\text { Recognition of how local } \\
\text { factors contribute to diversity } \\
\text { urban sustainability } \\
\text { challenges and solutions. }\end{array}$ & & $\begin{array}{l}\text { Incorporation of diverse } \\
\text { knowledge domains to urban } \\
\text { sustainability research } \\
\text { questions. }\end{array}$ & \\
\hline $\begin{array}{l}\text { Anticipatory } \\
\text { thinking }\end{array}$ & $\begin{array}{l}\text { Consideration of diverse } \\
\text { perspectives to avoid } \\
\text { conflict. }\end{array}$ & $\begin{array}{l}\text { Consideration of context when } \\
\text { analyzing urban problems or } \\
\text { solutions. }\end{array}$ & & $\begin{array}{l}\text { Consideration of how } \\
\text { different disciplinary } \\
\text { approaches may or may not } \\
\text { fully address research } \\
\text { questions. }\end{array}$ & $\begin{array}{l}\text { Consideration of diverse } \\
\text { perspectives to avoid } \\
\text { conflict. }\end{array}$ \\
\hline $\begin{array}{l}\text { Normative } \\
\text { thinking }\end{array}$ & $\begin{array}{l}\text { Consideration of diverse } \\
\text { perspectives to avoid } \\
\text { conflict. }\end{array}$ & $\begin{array}{l}\text { Not privileging certain } \\
\text { cultural contexts over others. }\end{array}$ & $\begin{array}{l}\text { Consideration of winners } \\
\text { and losers when } \\
\text { researching potential } \\
\text { sustainability solutions. }\end{array}$ & $\begin{array}{l}\text { Not privileging certain ways } \\
\text { of knowing over others. }\end{array}$ & $\begin{array}{l}\text { Consideration of diverse } \\
\text { perspectives to avoid } \\
\text { conflict. }\end{array}$ \\
\hline $\begin{array}{l}\text { Strategic } \\
\text { thinking }\end{array}$ & $\begin{array}{l}\text { Leverage cultural diversity } \\
\text { to research and test suite of } \\
\text { potential sustainability } \\
\text { solutions. }\end{array}$ & $\begin{array}{l}\text { Leverage cultural diversity to } \\
\text { research and test suite of } \\
\text { potential sustainability } \\
\text { solutions. }\end{array}$ & $\begin{array}{l}\text { Appropriate, translate, and } \\
\text { adapt knowledge of local } \\
\text { contexts in } \\
\text { problem-solving efforts. }\end{array}$ & $\begin{array}{l}\text { Leverage disciplinary } \\
\text { diversity to more fully } \\
\text { address research questions } \\
\text { or test sustainability } \\
\text { solutions. }\end{array}$ & $\begin{array}{l}\text { Cultivate dynamic that } \\
\text { draws on teammate } \\
\text { strengths and supports } \\
\text { team and individual } \\
\text { development. }\end{array}$ \\
\hline $\begin{array}{l}\text { Interpersonal } \\
\text { skills }\end{array}$ & $\begin{array}{l}\text { Navigation of local } \\
\text { contexts and multi-cultural } \\
\text { team dynamics. }\end{array}$ & $\begin{array}{l}\text { Navigation of local contexts } \\
\text { and multi-cultural team } \\
\text { dynamics. }\end{array}$ & $\begin{array}{l}\text { Navigation of local } \\
\text { contexts and multi-cultural } \\
\text { team dynamics. }\end{array}$ & $\begin{array}{l}\text { Ability to bridge disciplines } \\
\text { in team settings and in } \\
\text { public communication. }\end{array}$ & $\begin{array}{l}\text { Navigation of local } \\
\text { contexts, cultural, and } \\
\text { disciplinary perspectives. }\end{array}$ \\
\hline
\end{tabular}




\section{Virtual Collaboration}

Virtual collaboration is not a full substitute for in-person interactions, despite our best efforts. Indeed, hundreds of e-mails and dozens of hours of video chats could not compensate for several transatlantic visits that were necessary to plan and consolidate the syllabus and course organization. In general, planning challenges require a lot of good will, trust, flexibility, and understanding in order to come up with feasible and acceptable solutions, sometimes last minute. Therefore, we are still seeking and exploring additional strategies for successful virtual collaboration.

Beyond these more intangible issues of virtual collaboration are the invariable rules of using technologies in the classroom. If you need to use it, and your entire meeting revolves around the need of a technology to work correctly, it will fail sometimes (we have empirical evidence). Institutional technology support (technician), patient students, and good-humored instructors are instrumental in surmounting such technical hiccups.

\section{Cross-Disciplinary and Cross-Cultural Collaboration}

The Global Classroom seeks to equip students with tools and experiences on working in interdisciplinary, cross-cultural teams. The same applies to the instructors. We often experience first-hand the need for patience, broad perspectives, and flexibility when it comes to attempting to globalize the educational landscape. Different epistemological perspectives manifest in the approaches we take to planning Global Classroom activities. Tensions are often palpable between those with more process-driven, meticulous approaches vs. those with a more "creative” attitude, for instance, when developing proposals, work plans, and course material. These tensions, when not addressed, can lead to frustration and reluctance to fully engage in continuous deliberation and collaboration. If not addressed early, this could lead to resentment capable of undermining the entire Global Classroom effort. In response, we are learning to practice the very process checks we teach to our students about successful international collaboration; listen to colleagueperspectives, respect the work being done, question assumptions about differences in approaches, and communicate questions appropriately, and institute regular assessment of team interactions. So far we have been successful.

\section{Conclusion}

This article started out with quality criteria for international educational experiences to prepare students for confronting sustainability challenges crossing cultural, national, and geographical boundaries. With these criteria in hand, we reviewed student opportunities in international sustainability education. Our rough appraisal found that only one of seventeen programs reviewed fulfill all of the criteria. The Global Classroom Experiment was presented with its program inspiration, design, approach, and ability to deliver on the compiled criteria. Finally, we reviewed the challenges of designing a program that we find fulfills the quality criteria of international sustainability educational experiences.

The Global Classroom is but one program between two institutions supported by a generous external grant. While we find our model of international collaboration valuable, its scope is limited. True transformation of the landscape of international sustainability education will require more substantial change at the level of academic institutions. Such changes would necessarily affect administration, faculty, and students in different, yet interconnected ways.

Administration needs to work closely to navigate the challenges of potentially incompatible semester and vacation schedules, as well as establishing incentive structures for faculty, post-docs, and research and teaching assistants to tackle these challenges. In addition, finding ways to leverage institutional resources for sufficient virtual collaboration and technological support, as well as intermittent travel funding, is essential. With institutional support, we can imagine generic global classroom teams securing outside funding of site visits, but only with the demonstrated institutional support for other facets of the classroom experience as we have experienced from Arizona State and Leuphana universities.

Faculty need to develop skills in international collaboration and project management. In addition, faculty with valuable disciplinary perspectives but relatively untrained in working on interdisciplinary teams needs to learn to navigate the tension of such worldview-challenging experiences. Although at first difficult, we expect the benefits of such work to far exceed the costs, opening up new streams for fruitful research, travel, and educational opportunities for faculty and students alike.

Students need to develop exceptional flexibility as GlobalClassroom-like programs come online. At a most basic level, the majority of the students may never have experienced challenges to their worldviews. In addition, those participating in the class must be prepared to manage heavy workloads that may fall at odd-times in their conventional semester as accommodations are made to pair university schedules. Students also need to be flexible regarding out-of-class working hours, as international peers may not be easily reached during conventional work times (e.g., the evening hours for one set of students may be the class hours for another). Where international travel is involved, faculty and administration need to coach students on how to secure outside funding (to ensure that all who are interested have access to these international experiences), as well as on proper travel etiquette.

All parties involved need to adopt to and integrate the promising practices of virtual educational technologies. From inclass video conferencing to out-of class times, emails, and workflows, all parties will likely need to cultivate patience and skill in navigating the online world. These forays into virtual spaces, however, allows universities to tap into the growing body of resources available to online education efforts. A fully global classroom can take advantage of "flipped classroom" models (Strayer, 2007) in which students are free to interact with lesson content outside of the class and instructors are free to use class time to engage students on the nuances of crosscultural perspectives, collaboration and knowledge translational and adaptation. In addition, such a "flipped" model would also secure valuable and scarce time in which students know they will be able to work together on joint projects, using the paradigm of problem- and project-based learning (Steinemann \& Asce, 2003; Wiek et al., 2013).

A critical step to internationalizing sustainability education is to establish the standards vital to ensuring quality student experiences. The Global Classroom can serve as a real-world laboratory for consolidating such standards and practices. Additional "meta research" along a clearly structured research design is required to evaluate, generalize, and transfer the insights gained. While more detailed studies need to be done, our 
review demonstrates the distance to go in closing the gap between the knowledge, skills, and perspectives students need to, and the opportunities they have to hone these skills in international sustainability education. Future global classrooms will also need to press the envelope of cross-cultural fluency. Our Germany-US collaboration looks much different than, say, a US-China or Germany-South Africa collaboration might. Should our institutions choose advance the ideas embodied by the Global Classroom model, multiple and diverse partnerships will be required to encourage broad-based cultural exchanges. The suite of institutions providing student opportunities in international sustainability education, universities, like Arizona State University, Leuphana University of Lüneburg, and those reviewed in this article, will play a critical role in providing students with the international learning opportunities they need to tackle sustainability problems in a globalized world.

\section{Acknowledgements}

The authors would like to thank their colleagues at Arizona State University and Leuphana University of Lüneburg, including Beatrice John, Sacha Kagan, Jane Maienschein, Richard Creath, Sean Cohmer, Andrew Ells, Irma Sandercock, Charles Kazilek, Nils Ole Oermann, Robert Page and Sascha Spoun and our first cohort of Global Classroom students for their collaborative engagement and support in the first Global Classroom. The authors acknowledge financial support from the Stiftung Mercator.

\section{REFERENCES}

Brundiers, K., \& Wiek, A. (2011). Educating students in real-world sustainability research: Vision and implementation. Innovative Higher Education, 36, 107-124. doi:10.1007/s10755-010-9161-9

Brundiers, K., \& Wiek, A. (2013). Do we teach what we preach? An international comparison of problem- and project-based learning courses in sustainability. Sustainability, 5, 1725-1746.

Crow, M. M. (2010). Organizing teaching and research to address the grand challenges of sustainable development. BioScience, 60, 488489. doi:10.1525/bio.2010.60.7.2

De Haan, G. (2006). The BLK “21” programme in Germany: A “Gestaltungskompetenz"-based model for education for sustainable development. Environmental Education Resources, 1, 19-32. doi:10.1080/13504620500526362

Elkana, Y., Laubichler, M. D., \& Wilkins, A. S. (2010). Call to reshape university curricula. Nature, 467, 788. doi:10.1038/467788c

Ferrer-Balas, D., Adachi, J., Banas, S., Davidson, C. I., Hoshikoshi, A.,
Mishra, A., Motododa, Y., Onga, M., \& Ostwald, M. (2008). An international comparative analysis of sustainability transformation across seven universities. International Journal of Sustainability in Higher Education, 9, 295-316. doi:10.1108/14676370810885907

Lang, D. J., \& Wiek, A. (2012). The role of universities in fostering urban and regional sustainability. In H. A. Mieg, \& K. Töpfer (Eds.), Institutional and social innovation for sustainable urban development (pp. 393-411). London: Earthscan.

Rowe, D. (2007). Education for a sustainable future. Science, 317, 323324. doi:10.1126/science.1143552

Sipos, Y., Battisti, B., \& Grimm, K. (2008). Achieving transformative sustainability learning: Engaging head, hands and heart. International Journal of Sustainability in Higher Education, 9, 68-86. doi:10.1108/14676370810842193

Steinemann, A., \& Asce, M. (2003). Implementing sustainable development through problem-based learning: Pedagogy and practice. Journal of Professional Issues in Engineering Education and Practice, 129, 216-224. doi:10.1061/(ASCE)1052-3928(2003)129:4(216)

Strayer, J. F. (2007). The effect of the classroom flip on the learning environment: A comparison of learning activity in a traditional classroom and a flip classroom that used an intelligent tutoring system. Ph.D. Thesis, Columbus, OH: Ohio State University.

Thomas, I. (2009). Critical thinking, transformative learning, sustainable education, and problem-based learning in universities. Journal of Transformative Education, 7, 245-264. doi: $10.1177 / 1541344610385753$

Van der Leeuw, S., Wiek, A., Harlow, J., \& Buizer, J. (2012). How much time do we have? Urgency and rhetoric in sustainability science. Sustainability Science, 7, 115-120. doi:10.1007/s11625-011-0153-1

Whitmer, A., Ogden, L., Lawton, J., Sturner, P., Groffman, P. M., Schneider, L., Hart, D. et al. (2010). The engaged university: Providing a platform for research that transforms society. Frontiers in Ecology and the Environment, 8, 314-321. doi:10.1890/090241

Wiek, A., Withycombe, L., \& Redman, C. L. (2011a). Key competencies in sustainability-A reference framework for academic program development. Sustainability Science, 6, 203-218. doi:10.1007/s11625-011-0132-6

Wiek, A., Withycombe, L., Redman, C. L., \& Banas Mills, S. (2011b). Moving forward on competence in sustainability research and problem solving. Environment: Science and Policy for Sustainable Development, 53, 3-12. doi:10.1080/00139157.2011.554496

Wiek, A., Xiong, A., Brundiers, K., \& van der Leeuw, S. (2013). Integrating problem- and project-based learning into sustainability programs-A case study on the School of Sustainability at Arizona State University. International Journal of Sustainability in Higher Education, under Review.

Yasin, R. M., \& Rahman, S. (2011). Problem oriented project based learning (POPBL) in promoting education for sustainable development. Procedia Social and Behavioral Sciences, 15, 289-293. doi:10.1016/j.sbspro.2011.03.088 